\title{
ОПЫТ ИСПОЛЬЗОВАНИЯ СВЕРХБЫСТРОГО ИНСУЛИНА АСПАРТ+НИКОТИНАМИД У ДЕТЕЙ ОМСКОЙ ОБЛАСТИ, НАХОДЯЩИХСЯ НА ПОМПОВОЙ ИНСУЛИНОТЕРАПИИ
}

\author{
Юдицкая Т.А., Власенко Н.Ю., Юнгман Н.В., Каргаполова К.И., Кузнецова П.В. \\ БУЗОО «Областная детская клиническая больница», \\ ФГБОУ ВО «Омский государственный медицинский университет» Минздрава России, \\ г. Омск
}

Ключевые слова: сахарный диабет 1 типа; дети; помповая инсулинотерапия; флэш-мониторинг

В детском и подростковом возрасте часто не выдерживается пауза между постановкой ультракороткого инсулина и приемом пищи, что ведет к постпрандиальной гипергликемии (ППГ) и препятствует достижению целевого гликемического профиля. Со 2 октября 2020г. в РФ сверхбыстрый инсулин аспарт + никотинамид зарегистрирован для применения у детей, в том числе и в помпе.

Цель исследования: У пациентов на помповой инсулинотерапии оценить эффективность по оценке

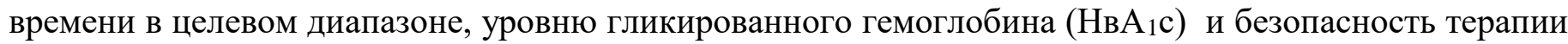
по количеству эпизодов гипогликемий, частоту замены инфузионных наборов, нежелательные реакции через 3 месяца после перевода на инсулин аспарт+никотинамид.

Материал и методы. По данным Федерального Регистра СД в Омской области наблюдаются 618 детей и подростков с СД 1 типа, средний уровень НвАс1 составляет 8,6\%. Количество детей достигших целевых значений $\left(\mathrm{HвA}_{1}\right.$ с менее 7\%) 22,74\%. У 30,3\% пациентов НbA1с более 9\%. На помповой инсулинотерапии находится 122 ребенка (19,7\%). Средний возраст детей на помповой инсулинотерапии 12 лет.

С января 2021 года на базе эндокринного отделения БУЗОО ОДКБ 57 детей с сахарным диабетом 1 типа были переведены на инсулин аспарт+никотинамид. Преимущественно жители города (40 и 17 человек соответственно). В том числе 15 детей на помповой инсулинотерапии. Помпы компании «Roche» 8 штук и «Medtronic» 7 помп. . Средний возраст детей при переводе 11,5лет (3-17лет). Средний уровень НвА 1 с - 7,8\%. Стаж диабета 5,3 года. Всем детям, кроме обязательного контроля при помощи глюкометра, на протяжении 14 дней проводилось флэш-мониторирование (Free Style Libre, Abbott). Вариабельность гликемии в начале наблюдения составила до 4 ммоль /л. Постпрандиальная гликемия в среднем составила 11 ммоль/л. Время нахождения в целевом диапазоне (3,9-10,0 ммоль/л) (TIR) - 43\%. Только у 1 пациента в анамнезе до перевода отмечались тяжелые гипогликемии, в остальных случаях отмечались легкие гипогликемии до 4 раз в неделю.

Результаты. Через 3 месяца наблюдения Нв $\mathrm{A}_{1}$ с снизился до 8,3\% (на 0,7\%) без изменения суточной дозы инсулина и расчетных коэффициентов. По данным флэш-мониторирования время нахождения в целевом диапазоне увеличилось до 67 \%. Вариабельность гликемии снизилась до 3 ммоль/л. Отмечалось снижение постпрандиальной гликемии до 8 ммоль/л. Эпизодов тяжелой гипогликемии на препарате не зарегистрировано. Среднее количество легких гипогликемий уменьшилось до 2 раз в неделю. Стоит отметить, что не изменилась частота замены инфузионных наборов у детей на помповой терапии. А также нет неприятных/ болезненных ощущений в месте введения канюли, нет аллергических реакций. Пациенты и родители отметили удобство терапии, так как инсулин аспарт+никотинамид водился непосредственно перед приемом пищи 
Выводы. Сверхбыстродействующий инсулин аспарт+никотинамид показал, большую эффективность в отношении $\mathrm{HbA1c}$, времени нахождения в целевом диапазоне по сравнению с предшествующей терапией прандиальными аналогами у детей с СД 1 типа на помповой инсулинотерапии. Безопасность новой терапии по критерию гипогликемий была выше. Перевод на инсулин аспарт+никотинамид не повлиял на частоту замены инфузионных наборов для помповой инсулинотерапии. Увеличилась комплаентность пациентов с СД1 типа. 